Check for updates

Cite this: RSC Adv., 2019, 9, 2906

\title{
Effects of water absorption of soybean seed on the quality of soymilk and the release of flavor compounds
}

\author{
Xingfei Li, iD Xu Liu, Yufei Hua, ${ }^{*}$ Yeming Chen, Xiangzhen Kong (iD \\ and Caimeng Zhang
}

\begin{abstract}
The water absorption of soybeans during soaking is directly related to the quality characteristics and the flavor properties of soybeans for processing. In this paper, the effects of water absorption of soybean seed on the quality of soymilk and the release of flavor compounds were investigated during soaking at $4{ }^{\circ} \mathrm{C}, 25^{\circ} \mathrm{C}$, and $50{ }^{\circ} \mathrm{C}$ at different $\mathrm{pH}$ values. The results showed that the water absorption rate increased as the soaking temperature and $\mathrm{pH}$ increased, while the equilibrium value was relatively stable. Peleg's equation with good fitting of the absorption kinetics was used to predict the hydration characteristics of undehulled soybean. MALDI-TOF/TOF-MS results showed that the major released proteins are basic 7S globulin, which is released in large amounts at high temperature. The water absorption of soybean seed significantly enhanced the extraction yields of protein, fat and solids of the prepared soymilk, and alkaline soaking $\mathrm{pH}$ further promoted the extraction of proteins and solids. A high soaking temperature can significantly decrease the required soaking time; however, it is unfavorable to the extraction yields of fat, proteins and solids, as well as the whiteness values and the particle sizes. The beany odor compounds of soymilk mainly consisted of hexanal, trans-2-hexenal, 1-octene-3-ol, hexanol, and 2-pentylfuran, and their contents were positively correlated with soaking temperature. A good balance of soymilk quality and flavor compound release can be achieved with soaking conditions of $25^{\circ} \mathrm{C}$ and $\mathrm{pH} 9$.
\end{abstract}

Received 27th September 2018

Accepted 8th January 2019

DOI: $10.1039 / c 8 r a 08029 a$

rsc.li/rsc-advances absorption of soybeans ${ }^{4}$ and the quality of the subsequent soy products, such as soymilk, tofu, and soygurt. Soaking at $40^{\circ} \mathrm{C}$ to $60{ }^{\circ} \mathrm{C}$ can decrease lipoxygenase activity and thus improve the digestibility of soybean proteins. ${ }^{5}$ However, high soaking temperatures induce greater loss of solids, such as proteins and isoflavones, into the aqueous medium. ${ }^{4}$ Prolonged soaking times are not necessary to generate additional softening of the grains because excessive soaking often results in bacterial growth and does not contribute to further water absorption. ${ }^{6}$

The degree of water absorption in the soybean soaking process directly affects the texture of the soybeans and their grinding characteristics during processing. Pan et al. found that the grinding characteristics of soybeans were only related to the equilibrium water absorption rate, regardless of soaking conditions. ${ }^{4}$ Water absorption of legumes has been investigated using several rather complex models. Joshi et al. studied the water absorption of three different types of lentils at different soaking temperatures; they reported that the water absorption process can be fitted using the Mitscherlich model at high temperatures $\left(50{ }^{\circ} \mathrm{C}\right.$ and $\left.85{ }^{\circ} \mathrm{C}\right)$, while this model is only acceptable for "Boomer" lentils at room temperature. ${ }^{7}$ Another typical fitting model is the Peleg equation, which has been used in recent years to model the water absorptions of different grains and foods during soaking; ${ }^{8-10}$ meanwhile, the 
relationship between the kinetic parameters and temperature can be further fitted by the Arrhenius equation or an empirical formula. ${ }^{11}$

Because most research focuses on the characteristics of water absorption, solid loss, moisture content, textural characteristics and grinding properties of soybeans, there is still a lack of systematic investigation of the subsequent quality of soybean products, such as soymilk and tofu. Giri et al. showed that soybeans became easier to grind after soaking in carbonate solution compared with immersion in deionized water or $\mathrm{NaOH}$ solution; the prepared soymilk was found to have high protein content and viscosity as well as less beany flavor. ${ }^{12}$ There is still controversy about whether the extraction rate of proteins and solids is the highest when the maximum water absorption rate is reached, and how the composition of soymilk changes. ${ }^{\mathbf{1 3 , 1 4}}$

The flavor of soymilk is an important factor affecting its acceptance. Many factors affect the flavor of soymilk, such as storage conditions, enzymes, and soaking conditions. ${ }^{15}$ Several methods have been used to reduce off-flavors of soybeans, including vacuum deodorization treatment and adding other flavor substances; pretreatment strategies mainly focus on how to prevent or reduce the formation of off-flavor compounds, such as blanching enzymes, dry bean refining, anaerobic pulping, and soaking treatment with acid or alkali solution. Badenhop et al. showed that when the soaking temperature was $50{ }^{\circ} \mathrm{C}$, the content of 1-octene-3-ol in soymilk increased with soaking time. ${ }^{16} \mathrm{Ha}$ et al. found that boiling soybeans in $\mathrm{NaHCO}_{3}$ solution can effectively inhibit the production of daidzein and genistein and decrease the formation of several volatile organic compounds in soybeans. ${ }^{17}$ However, the relationship between water adsorption and the quality and flavor release of soymilk is still poorly understood, and systematic study is required.

In this paper, the effects of soaking conditions on the kinetics of water absorption of soybeans were firstly studied to predict the adsorption equilibrium of soybeans at different $\mathrm{pH}$ values and temperatures. Then, the effects of soaking conditions on the release of proteins were further investigated using SDS-PAGE and MALDI-TOF/TOF-MS. Based on the above results, the quality of prepared soymilk was carefully studied with regard to the extraction yield of fat, proteins and solids of soymilk, as well as the changes in color and particle size. Finally, the volatile compounds in soymilk were evaluated by headspace GC-MS analysis.

\section{Materials and methods}

\subsection{Materials}

Dry soybeans (Glycine max) were purchased from a local supermarket and stored at room temperature in a dark room. All other reagents were of analytical grade.

\subsection{Soaking of dry soybeans}

$20 \mathrm{~g}$ dry soybeans were placed in a beaker containing $100 \mathrm{~mL}$ of deionized water and incubated at different soaking temperatures $\left(4{ }^{\circ} \mathrm{C}, 20{ }^{\circ} \mathrm{C}, 30{ }^{\circ} \mathrm{C}, 40{ }^{\circ} \mathrm{C}, 50{ }^{\circ} \mathrm{C}\right)$ and soaking times ( 0 to 24 h). Soaking experiments at pH 3 and $\mathrm{pH} 9$ were carried out using
$200 \mathrm{mM}$ pH 3 citrate buffer solution or $0.5 \% \mathrm{NaHCO}_{3}(\mathrm{pH} 9)$ solution.

The moisture content $\left(M_{t}\right)$ of the soybean seed was expressed as the difference in the soybean seed before and after soaking, as follows:

$$
M_{t}=\frac{W_{t}-W_{0}}{W_{0}} \times 100
$$

where $t$ is the soaking time $(\mathrm{h}) ; W_{t}$ is the mass of the soybeans after soaking; and $W_{0}$ is the mass of the soybeans before soaking.

\subsection{Analysis of soaking data with soaking models}

Peleg's model ${ }^{18}$ was used to model the water absorption of soybean seed during soaking. The equation is expressed as follows:

$$
M_{t}=M_{0}+\frac{t}{k_{1}+k_{2} t}
$$

where $M_{t}$ is the moisture content at time $t(\%), M_{0}$ is the initial moisture content (\%), $t$ is time (h), and $k_{1}$ and $k_{2}$ are the Peleg rate and Peleg capacity constant, respectively. $k_{1}$ is negatively correlated with sample water absorption rate $\left(\mathrm{h} \%{ }^{-1}\right)$, while $k_{2}$ is positively correlated with sample water absorption capacity $\left(\%^{-1}\right)$. When the soaking time is infinite, the equilibrium moisture content of the sample $M_{\mathrm{e}}=M_{0}+\frac{1}{k_{2}}$ can be obtained.

\subsection{Preparation of soymilk}

The soaked soybeans were mixed with water at a $1: 9$ mass ratio and pulped for $30 \mathrm{~s}$ using a JYL-C012 Joyoung Soymilk Maker (Joyoung, Hangzhou, China). Then, $500 \mathrm{~mL}$ of the mixture was filtered through a Buchner funnel to obtain the raw soymilk. The raw soymilk was heated at $95{ }^{\circ} \mathrm{C}$ for $10 \mathrm{~min}$ to obtain the cooked soymilk.

\subsection{SDS-PAGE and mass spectrometry of proteins}

The soaking solutions with different soaking conditions were collected and freeze-dried. Then, the protein distributions were analyzed by Tricine-SDS-PAGE according to our previous work. ${ }^{19}$ All the samples were dissolved in $2.0 \mathrm{~mL}$ loading solution and then reduced with $2 \%(\mathrm{v} / \mathrm{v}) 2$-mercaptoethanol in boiled water for 3 to $5 \mathrm{~min}$. $10 \mu \mathrm{L}$ of sample solution were loaded per well. Protein molecular weight markers were included in each gel. The electrophoresis was conducted using a DYY-8c vertical electrophoresis apparatus provided by LiuYi Biotechnology, Co., Ltd, (Beijing, China) at a constant voltage of $30 \mathrm{~V}$ for the stacking gel (4\%) and $100 \mathrm{~V}$ for the separation gel (16\%). The gel was stained with $0.05 \%$ Coomassie Brilliant Blue G-250.

The unknown proteins in the soaking solutions were identified by mass spectrometry (MALDI-TOF/TOF-MS). ${ }^{20}$ Briefly, the protein spots on the Tricine-SDS-PAGE gel were excised and destained using $30 \%(\mathrm{v} / \mathrm{v})$ acetonitrile containing $100 \mathrm{mM}$ $\mathrm{NH}_{4} \mathrm{HCO}_{3}$. The destained gel was then washed with $100 \%$ acetonitrile and incubated in $10 \mu \mathrm{L}$ reducing solution $(100 \mathrm{mM}$ DTT and $90 \mu \mathrm{L}$ of $100 \mathrm{mM} \mathrm{NH}_{4} \mathrm{HCO}_{3}$ ) for $30 \mathrm{~min}$ at $56^{\circ} \mathrm{C}$. After 
washing with $100 \%$ acetonitrile, $70 \mu \mathrm{L}$ of $100 \mathrm{mM} \mathrm{NH} \mathrm{HCO}_{3}$ and $30 \mu \mathrm{L}$ of $200 \mathrm{mM}$ iodoacetic acid were added, and the mixture was incubated for $20 \mathrm{~min}$ in the dark. After dehydrating the sample with $100 \%$ acetonitrile, $5 \mu \mathrm{L}$ of $10 \mu \mathrm{g} \mathrm{mL}^{-1}$ of trypsin were added and the solution was incubated at $37^{\circ} \mathrm{C}$ for $20 \mathrm{~h}$ to induce protein hydrolysis. The resulting peptide solution was incubated at $30{ }^{\circ} \mathrm{C}$ until a dry powder was obtained, and then the powder was dissolved in $3 \mu \mathrm{L}$ of $0.1 \%$ (v/v) TFA. For MALDITOF/TOF analysis, $0.7 \mu \mathrm{L}$ of the sample and $0.7 \mu \mathrm{L}$ of 4 -hydroxy$\alpha$-cyanocinnamic acid (used as a matrix) were loaded on a MALDI target and air-dried. Mass spectrometric analysis was performed in batch mode using an ABI 4700 Proteomics Analyzer (Ultraflex TOF/TOF, Bruker Daltonik GmbH, Bremen, Germany). Mass spectrum data were analyzed using 203 flexAnalysis software; then, we searched for plant proteins in the NCBInr database, and only those protein hits were evaluated.

\subsection{Measurement of volatile flavor substances}

Volatile substance analysis was performed according to the method reported by Achouri et al. ${ }^{21}$ with some modifications. Carboxen-polydimethylsiloxane (CAR-PDMS) fiber $(85 \mu \mathrm{m})$ was used to perform headspace solid-phase microextraction (HSSPME). $5 \mathrm{~mL}$ sample solution and $1 \mu \mathrm{L}$ of 2-methyl-3heptanone $\left(0.25 \mathrm{mg} \mathrm{mL}^{-1}\right)$ were placed into $10 \mathrm{~mL}$ glass vials, and a gas-tight syringe was used for sample preparation at $40{ }^{\circ} \mathrm{C}$ for $30 \mathrm{~min}$.

A gas chromatograph-mass spectrometer (GC-MS, $1200 \mathrm{~L}$, Varian, USA) equipped with a DB-WAX column $(0.25 \mu \mathrm{m}, 30 \mathrm{~m}$ $\times 0.25 \mathrm{~mm}$ ) was used to analyze the volatile substances. The temperature was programmed as follows: the initial temperature was maintained at $40{ }^{\circ} \mathrm{C}$ for $3 \mathrm{~min}$ and then increased to $100{ }^{\circ} \mathrm{C}$ at $6{ }^{\circ} \mathrm{C} \mathrm{min}^{-1}$. The temperature was then increased to $230{ }^{\circ} \mathrm{C}$ at $10{ }^{\circ} \mathrm{C} \mathrm{min}^{-1}$ and held for $7 \mathrm{~min}$. The adsorbed volatiles in the fiber were desorbed without splitting at $260{ }^{\circ} \mathrm{C}$ for $7 \mathrm{~min}$. Compounds were identified based on the National Institute of Standards and Technology (NIST) database through a Saturn mass spectra library search.

\subsection{Color analysis of soymilk}

Raw soymilk and cooked soymilk were placed in cuvettes, and their surface colors were determined with a colorimeter (Minolta, CR-310, Ramsey, NJ) using the Hunter Lab color scale. Before each test, the colorimeter was calibrated using a Minolta standard-white reflector, and the light source was a pulsed xenon lamp. Data were represented by the $L^{*}$ (brightness/ darkness), $a^{*}$ (redness/greenness) and $b^{*}$ (yellowness/ blueness) values of the international color system. Each sample was tested in duplicate.

\subsection{Particle sizes of soymilk}

The particle sizes of raw soymilk and cooked soymilk were measured using a Zetasizer Nano ZS instrument (Malvern, UK). This system employs a $633 \mathrm{~nm}$ laser and a fixed scattering angle $\left(173^{\circ}\right)$ that is sufficiently high to justify neglect of the contribution from rotational diffusion effects to the autocorrelation files. The protein with a 1.450 refractive index (RI) was selected as the material, and water was selected as the dispersant $(0.8872$ cP, RI: 1.330). The soymilk was diluted 100 times before the experiment, and each sample was tested at $25.0 \pm 0.1{ }^{\circ} \mathrm{C}$. Each test was performed in duplicate.

\subsection{Statistical analysis}

All the measurements were performed three times with parallel samples. Statistical significance analysis $(p \leq 0.05)$ was performed using the SPSS 13.0 statistical analysis program. The data shown in the corresponding figures are the mean values with the standard deviation.

\section{Results and discussion}

\subsection{Kinetics of water absorption of soybean seed}

Fig. 1 shows the water absorption rate as a function of soaking temperature and time. The maximum water absorption was around $130 \%$, reached after soaking at $4{ }^{\circ} \mathrm{C}$ for $24 \mathrm{~h}, 20{ }^{\circ} \mathrm{C}$ for $12 \mathrm{~h}, 30^{\circ} \mathrm{C}$ for $9 \mathrm{~h}, 40{ }^{\circ} \mathrm{C}$ for $5 \mathrm{~h}$, and $50{ }^{\circ} \mathrm{C}$ for $3 \mathrm{~h}$, respectively. This value is very similar to the $129 \%$ value reported by Chopra et $a l .{ }^{22}$ The water absorption curves display typical water intake behavior in legumes. ${ }^{23,24}$ The soaking process of dry soybeans mainly depends on the driving force induced by the difference in moisture content at the saturation time and at a certain time; therefore, the equilibrium at different temperatures should theoretically be roughly equal, as shown in Fig. 1 . The moisture content decreased slightly after soaking for $3 \mathrm{~h}$ at $50{ }^{\circ} \mathrm{C}$; this may be due to the release of other substances, such as solid matter, from the soaked soybeans. Similar results have been reported for other plant seeds, such as pasta sorghum, milled rice, and barley seeds. ${ }^{25-27}$

The water absorption curves were fitted with Peleg's equation, eqn (2), and the related parameters are shown in Table 1. The coefficients of regression, $R^{2}$, for the four different temperatures varied from 0.966 to 0.995 . This indicates a very good fit of the model to the experimental data and suggests that Peleg's equation is well suited to describing the water absorption of soybean seed during soaking. The results also showed

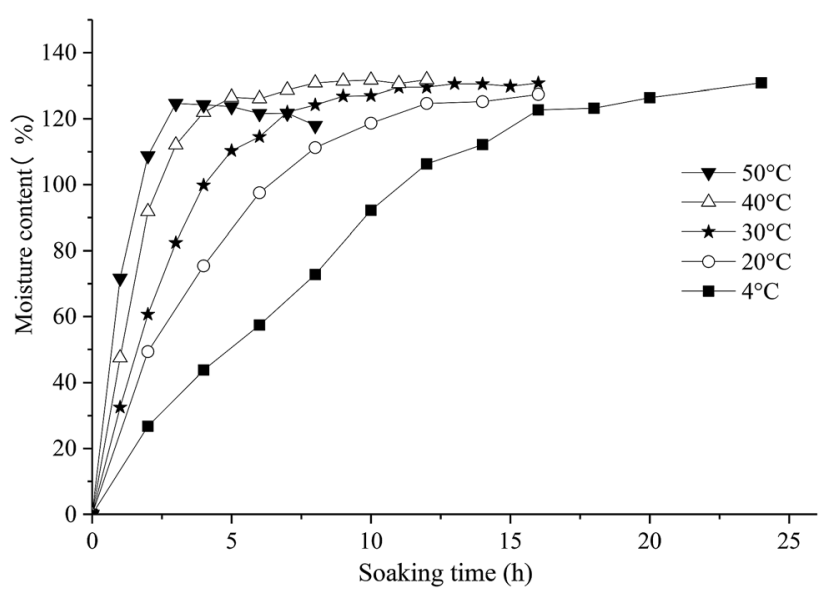

Fig. 1 Moisture content of soybeans at different soaking temperatures and times. 
Table 1 Peleg's parameters of soybean seed soaked at different temperatures

\begin{tabular}{|c|c|c|c|c|c|}
\hline \multirow{2}{*}{$\begin{array}{l}\text { Peleg's } \\
\text { equation constant }\end{array}$} & \multicolumn{5}{|c|}{ Temperature $\left({ }^{\circ} \mathrm{C}\right)$} \\
\hline & 4 & 20 & 30 & 40 & 50 \\
\hline$k_{1}$ & 0.0674 & 0.0272 & 0.0170 & 0.0093 & 0.0049 \\
\hline$k_{2}$ & 0.0044 & 0.0059 & 0.0062 & 0.0065 & 0.0073 \\
\hline$R^{2}$ & 0.9869 & 0.9950 & 0.9815 & 0.9711 & 0.9656 \\
\hline$W_{0}$ & 14.84 & 36.83 & 58.86 & 107.76 & 204.50 \\
\hline$M_{\mathrm{e}}$ & 226.24 & 169.20 & 160.26 & 153.85 & 137.55 \\
\hline
\end{tabular}

that $k_{1}$ decreased with increasing temperature, while the initial water absorption rate $W_{0}$, equal to $1 / k_{1}$, increased with increasing temperature. Here, the Arrhenius equation was additionally used to construct the relationship between the constant $k_{1}$ and temperature: ${ }^{28}$

$$
\ln \frac{1}{k_{1}}=\ln k_{0}-\frac{E}{R} \times \frac{1}{T}
$$

Then:

$$
\ln \frac{1}{k_{1}}=20.75-5019.06 \times \frac{1}{T}\left(R^{2}=0.9901\right)
$$

It can be seen that the linear coefficient of the equation is good $\left(R^{2}=0.9901\right)$; thus, the Arrhenius equation can better express the influence of temperature during soybean soaking.

There is no unified description of the relationship between the capacity constant $K_{2}$ and temperature depending on the sample material. A simple linear fit was applied to obtain the following equation:

$$
k_{2}=6.9152 \times 10^{-5} \mathrm{~T}-0.0146\left(R^{2}=0.9476\right)
$$

In this study, $k_{2}$ increased with increasing temperature, which is consistent with the results previously reported by Jideani et al. ${ }^{29}$

To verify the effectiveness of Peleg's equation, we further investigated the water absorption of soybean seed (with or without dehulling) at $4{ }^{\circ} \mathrm{C}, 25{ }^{\circ} \mathrm{C}$ and $50{ }^{\circ} \mathrm{C}$, as shown in Fig. 2 .

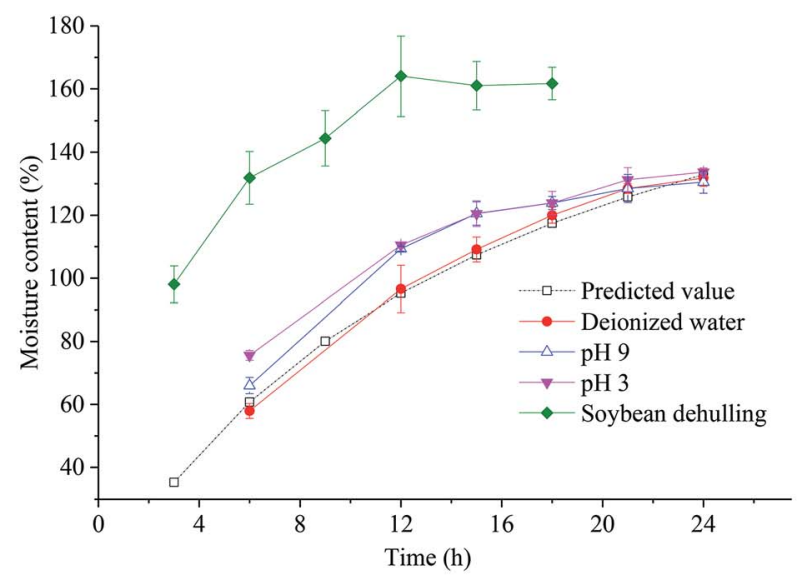

(a)

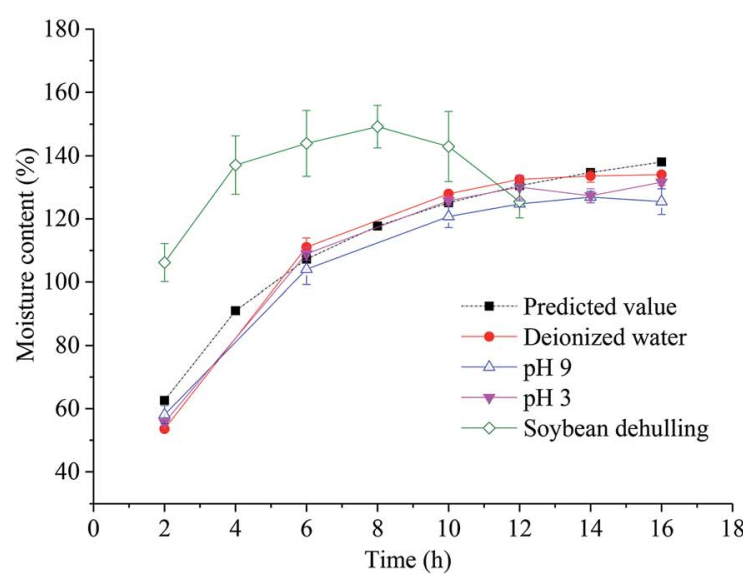

(b)

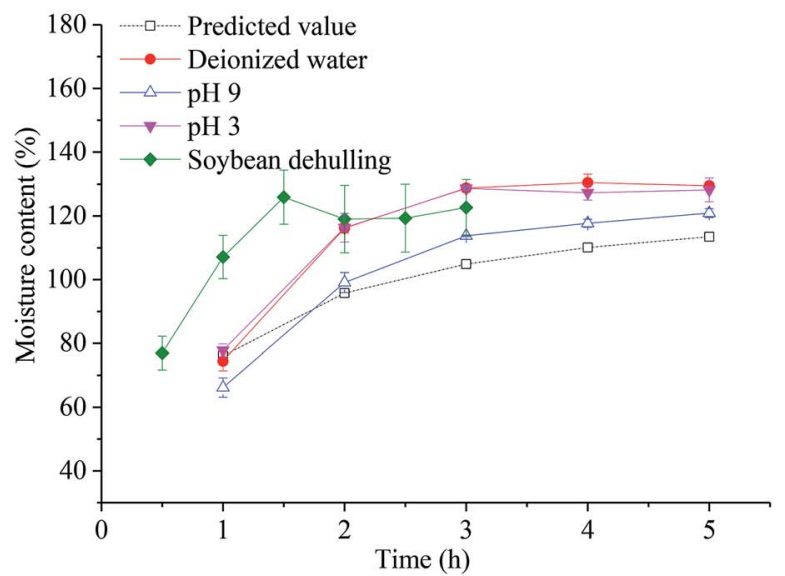

(c)

Fig. 2 Moisture absorption characteristics and predicted Peleg models fitted on undehulled and dehulled soybeans during soaking at different temperatures: (a) $4{ }^{\circ} \mathrm{C}$; (b) $25^{\circ} \mathrm{C}$; (c) $50{ }^{\circ} \mathrm{C}$ at different soaking $\mathrm{pH}$ values. 
At $4{ }^{\circ} \mathrm{C}$ and $50{ }^{\circ} \mathrm{C}$, good fitting of the water absorption curves for undehulled soybean with Peleg's equation was obtained in neutral $\mathrm{pH}$ conditions (deionized water). For the $4{ }^{\circ} \mathrm{C}$ soaking treatment, the water absorption became faster when soaking in acid or alkaline $\mathrm{pH}$ solution; for the $50{ }^{\circ} \mathrm{C}$ soaking treatment, the water absorption became slower in alkaline soaking solution; there was no significant difference in water absorption $(p>$ 0.05 ) between different soaking $\mathrm{pH}$ values for the $25^{\circ} \mathrm{C}$ soaking treatment. Therefore, there were some deviations from the predictions by Peleg's equation when the $\mathrm{pH}$ or temperature was changed. However, different soaking treatments achieved very similar equilibrium values, suggesting the independence of the water adsorption saturation of soybeans. For the $25{ }^{\circ} \mathrm{C}$ soaking treatment, Peleg's equation could also be used to predict the water absorption of undehulled soybeans at three different $\mathrm{pH}$ values, and the changes in $\mathrm{pH}$ had insignificant effects $(p>0.05)$ on the process of water absorption. These results show that the process of water absorption varied with the soaking conditions ( $\mathrm{pH}$, temperature), while the water adsorption equilibrium value remained relatively stable and was not affected by these factors.

However, the fitting equation was not suitable for dehulled soybeans because a large deviation $(p<0.05)$ from the predicted values was observed. As shown in Fig. 2, at the soaking temperatures of $4{ }^{\circ} \mathrm{C}, 25{ }^{\circ} \mathrm{C}$ and $50{ }^{\circ} \mathrm{C}$, the water absorption rates of the soybeans after dehulling were greater $(p<0.05)$ than those of the undehulled soybeans, while the time required to reach water adsorption equilibrium greatly decreased due to the absence of the seed coat (which prevents the free intake of water).

\subsection{Influence of soaking conditions on the release of protein components}

Although different soaking treatments can obtain very similar equilibrium values of water adsorption, the effects of soaking conditions on the release of components are still unclear. The released protein components after soaking were investigated using SDS-PAGE, and the results are shown in Fig. 3. It was found that after soaking at low temperatures $\left(4{ }^{\circ} \mathrm{C}\right.$ and $25{ }^{\circ} \mathrm{C}$, Fig. $3 \mathrm{~b}$ and $\mathrm{c}$ ), some known and unknown proteins were found in the soybean seed exudates. According to their molecular weights and soybean protein isolate (SPI) compositions (Fig. 3c), the known protein bands corresponded to the $\alpha, \alpha^{\prime}$, and $\beta$ subunits of $\beta$-conglycinin (7S globulin) and the $\mathrm{AB}$ (acidicbasic) and B (basic) subunits of glycinin (11S globulin), similar

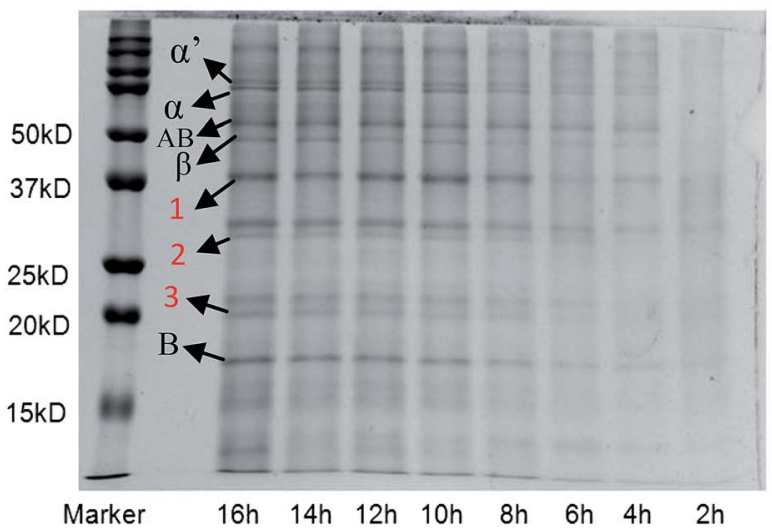

(a)

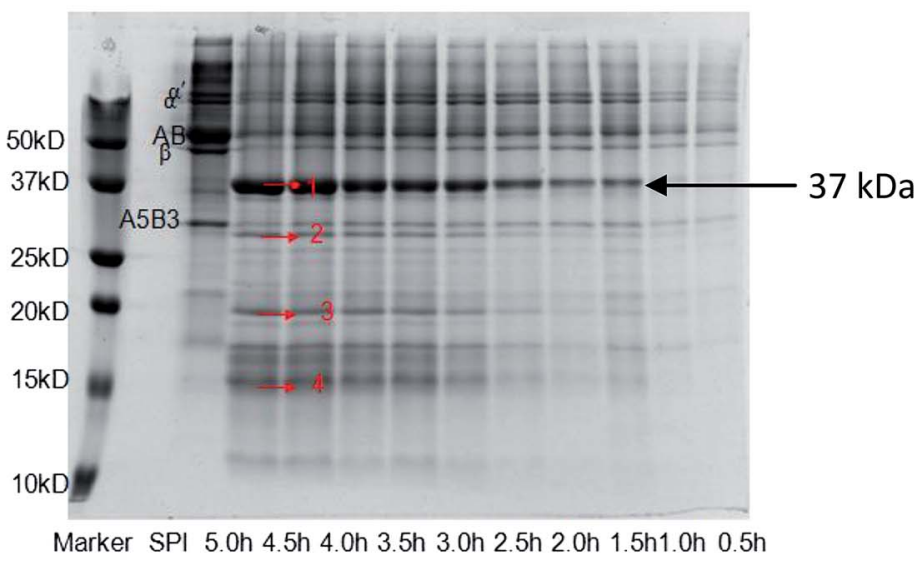

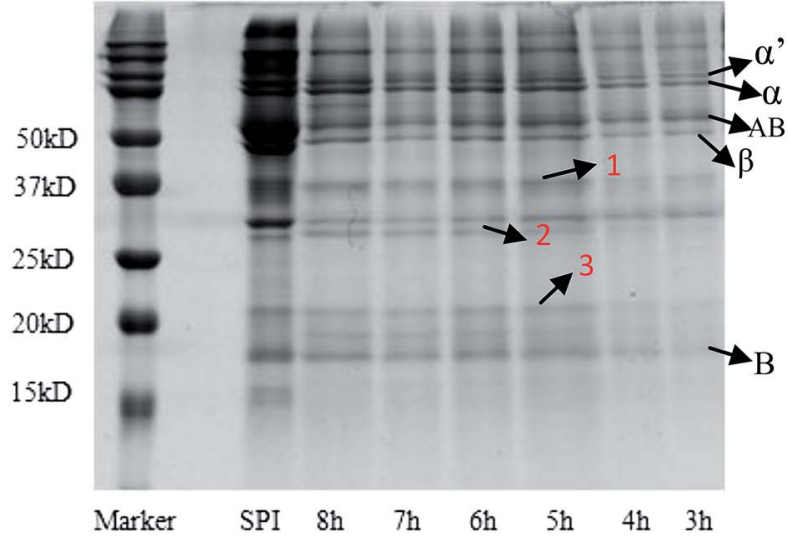

(b)

(c)

Fig. 3 SDS-PAGE of proteins released from soybean seeds incubated in warm water at (a) $20{ }^{\circ} \mathrm{C}$; (b) $40{ }^{\circ} \mathrm{C}$; (c) $50{ }^{\circ} \mathrm{C}$. 
to results observed in other studies. ${ }^{30,31}$ With increasing soaking time, the release of $7 \mathrm{~S}$ and $11 \mathrm{~S}$ proteins increased. As is well known, 7S and $11 \mathrm{~S}$ proteins are seed storage proteins that are stored in organelles. In dry soybean seeds, these proteins are protected by the seed coat. However, after soaking in warm water, our confocal laser scanning microscopy results (unpublished data) showed that the structure of the seed coat became increasingly loose, and some space between cells appeared after a certain soaking time. Therefore, $7 \mathrm{~S}$ and $11 \mathrm{~S}$ proteins will be released by the force of the concentration difference, and the release rate depends on the soaking temperature and soaking time.

Apart from the seed storage proteins, the unknown proteins found in the soybean seed exudates are named bands 1, 2, 3 and 4 (Fig. 3c) in this paper, respectively. Especially, the concentration of band 1 (around $37 \mathrm{kDa}$ ) was greatly enhanced after soaking at high temperature $\left(50{ }^{\circ} \mathrm{C}\right)$. These unknown protein bands were further identified by MALDI-TOF/TOF-MS. As shown in Table 2, bands $1-4$ were matched to basic $7 \mathrm{~S}$ globulin (G. $\max$ ), endo-1,3-beta-glucanase, $24 \mathrm{kDa}$ seed coat protein precursor (G. max), and seed maturation protein PM22 (G. max), respectively. The $24 \mathrm{kDa}$ seed coat protein precursor (SC24) is present in the aleurone layer or parenchyma of the seed coat; it is a newly discovered plant defense protein with carboxylate binding activity. ${ }^{32}$ The $37 \mathrm{kDa}$ protein was identified as alkaline 7S globulin (Bg7S), which is an extracellular matrix protein; ${ }^{33}$ it was released in large amounts at high temperature, indicating that the cell wall structure is destroyed and that water is more likely to enter the cells. Thus, the water absorption rate of the soybeans accelerated at $50{ }^{\circ} \mathrm{C}$. Bg7S is rapidly released when soybean seeds are immersed in water at $50{ }^{\circ} \mathrm{C}$ to $60^{\circ} \mathrm{C} .{ }^{34,35}$ When the soaking temperature was less than $40^{\circ} \mathrm{C}$, a small amount of Bg7S was released (as seen in Fig. $3 \mathrm{a}$ and b), which is consistent with previous reported results. ${ }^{36}$ However, protease inhibitors were not detected in the soybean seed exudates in the present case, although they were reported in studies by Palavalli et al. ${ }^{36}$ and Hirano et $a .^{34}$

\subsection{Effects of soaking conditions on the quality of soymilk}

3.3.1 Extraction yields of fat, proteins and solids in soymilk. Before preparing soymilk, the beating time should be optimized to obtain a high soymilk yield. In our preliminary experiment, considering the relationships between beating time, soaking conditions, and protein and solid extraction rates, a $30 \mathrm{~s}$ beating time was selected for the next experiment.
Fig. 4 shows the fat extraction yields of soymilk as a function of soaking time at various soaking $\mathrm{pH}$ values and temperatures. For soaking at $\mathrm{pH} \mathrm{9,} \mathrm{the} \mathrm{maximum} \mathrm{fat} \mathrm{extraction} \mathrm{yields} \mathrm{were}$ $80.93 \%\left(4{ }^{\circ} \mathrm{C}\right), 79.02 \%\left(25^{\circ} \mathrm{C}\right)$, and $73.81 \%\left(50{ }^{\circ} \mathrm{C}\right)$ after $18 \mathrm{~h}$, $12 \mathrm{~h}$ and $3 \mathrm{~h}$ of soaking, respectively. The corresponding water absorption rates were $123.89 \%, 124.76 \%$ and $113.79 \%$, respectively. When soaked in $\mathrm{pH} 3$ solution, the maximum fat extraction yields were $79.31 \%\left(4{ }^{\circ} \mathrm{C}\right), 79.52 \%\left(25{ }^{\circ} \mathrm{C}\right)$, and $65.39 \%\left(50{ }^{\circ} \mathrm{C}\right)$ after $24 \mathrm{~h}, 10 \mathrm{~h}$ and $3 \mathrm{~h}$, respectively; the water absorption rates were $133.68 \%, 125.74 \%$ and $128.68 \%$, respectively. Therefore, the maximum fat extraction yield was lowest at $50{ }^{\circ} \mathrm{C}$ and $\mathrm{pH} 3$; meanwhile, at $4{ }^{\circ} \mathrm{C}$ and $\mathrm{pH} 9$, the maximum fat extraction yield was the highest. These results also showed that the extraction of fat had a relatively positive correlation with the soaking time and was negatively correlated with the soaking temperature.

At soaking temperatures of $4{ }^{\circ} \mathrm{C}$ and $25{ }^{\circ} \mathrm{C}$, there was no significant difference $(p>0.05)$ in the fat extraction yields at different $\mathrm{pH}$ values. For $50{ }^{\circ} \mathrm{C}$ soaking treatment, the fat extraction yields were lower at $\mathrm{pH} 3$ and $\mathrm{pH} 9$ than that at neutral $\mathrm{pH}$, especially at $\mathrm{pH} 3(p<0.05)$. At high temperature and acidic $\mathrm{pH}$, some fat compounds may be lost due to hydrolysis; meanwhile, under alkaline conditions, fat saponification can occur at $\mathrm{pH}$ 9, which can also decrease the fat extraction yield. At soaking temperatures of $4{ }^{\circ} \mathrm{C}$ and $25{ }^{\circ} \mathrm{C}$, the hydrolysis and saponification reactions cannot readily occur; thus the fat extraction yields did not appear to be affected by the changes in $\mathrm{pH}$.

As shown in Fig. 5, the protein extraction yield increased gradually with increasing soaking time for soybeans soaked at $4{ }^{\circ} \mathrm{C}$. Soaking at $\mathrm{pH} 3$ or $\mathrm{pH} 9$ obviously improved the protein extraction yields compared with neutral soaking $\mathrm{pH}$. For the $25{ }^{\circ} \mathrm{C}$ and $50{ }^{\circ} \mathrm{C}$ soaking treatments, compared to neutral soaking $\mathrm{pH}$, soaking at alkaline $\mathrm{pH}(\mathrm{pH} 9)$ improved the protein extraction yield of soymilk, while soaking at acid $\mathrm{pH}(\mathrm{pH} 3)$ significantly decreased $(p<0.05)$ the protein extraction yield. The highest and lowest maximum protein extraction yields were $80.06 \%$ and $65.01 \%$ when soaking at $25{ }^{\circ} \mathrm{C}$, pH 9 and $50{ }^{\circ} \mathrm{C}, \mathrm{pH}$ 3 , respectively. In an acidic environment, the formation of $11 \mathrm{~S}$ globulin aggregates is promoted by hydrogen bonding ${ }^{37}$ and the dissolution rate will decrease during grinding of soaked soybeans, resulting in a decrease in the protein extraction yield. On the other hand, increased viscosity of the slurry soybean mixture after grinding was observed after soaking at $\mathrm{pH} 3$, which is disadvantageous for protein extraction.

Fig. 5 shows that the protein concentration of soymilk showed a similar trend to that observed in the protein

Table 2 Proteins identified in the soybean seed exudates after SDS-PAGE separation and MALDI-TOF/TOF MS

\begin{tabular}{lllll}
\hline Band & Protein ID & $M_{\mathrm{r}}{ }^{a}$ & $p \mathrm{I}^{a}$ & NBCInr accession no. \\
\hline 1 & Basic 7S globulin (G. max) & 47105 & 8.68 & gil356505878 \\
2 & Endo-1,3-beta-glucanase & 36638 & 8.88 & gil351723211 \\
3 & 24 kDa seed coat protein precursor (G. max) & 24611 & 9.14 & gil351721970 \\
4 & Seed maturation protein PM22 (G. max) & 16735 & 5.16 & gil351727629
\end{tabular}

${ }^{a}$ Molecular weights $\left(M_{\mathrm{r}}\right)$ and isoelectric points $(p \mathrm{I})$ are given as theoretical values. 


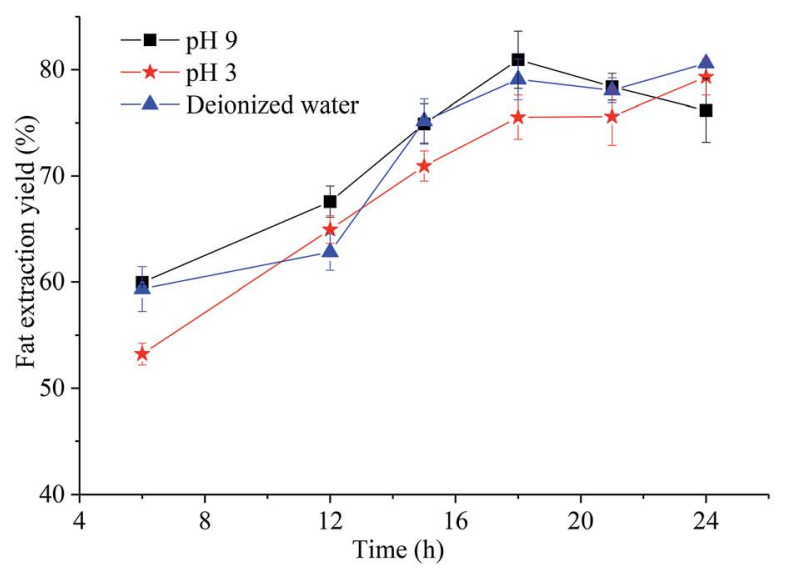

(a)

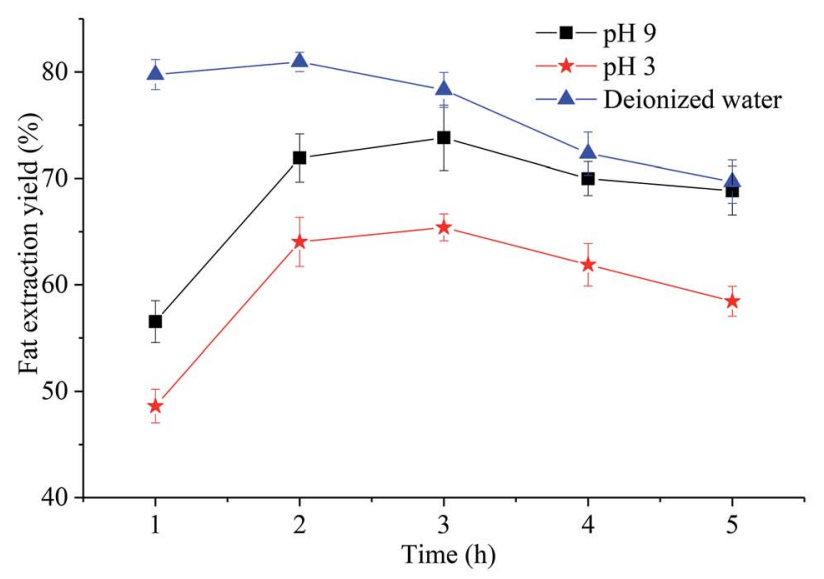

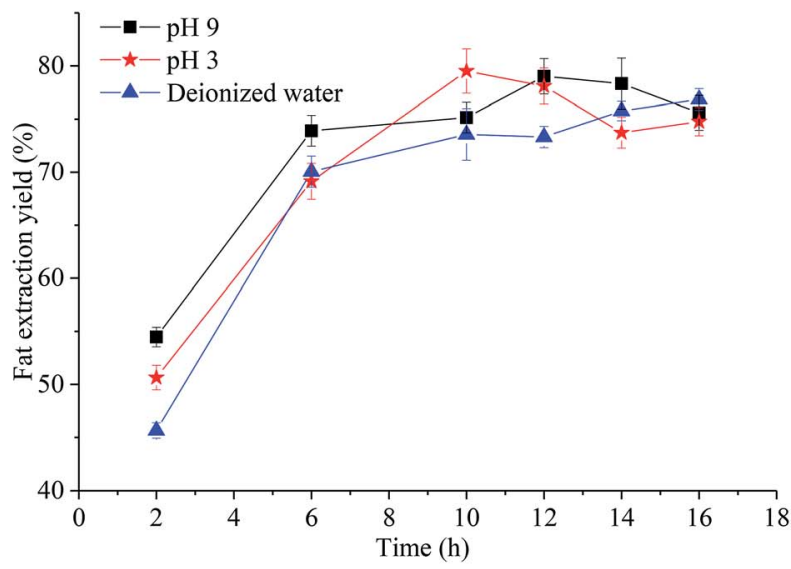

(b)

(c)

Fig. 4 Effects of the $\mathrm{pH}$ value of the soaking water on the extraction rate of fat from soymilk: (a) $4{ }^{\circ} \mathrm{C}$; (b) $25^{\circ} \mathrm{C}$; (c) $50{ }^{\circ} \mathrm{C}$.

extraction yield for soybeans soaked at $4{ }^{\circ} \mathrm{C}$. At soaking temperatures of $25{ }^{\circ} \mathrm{C}$ and $50{ }^{\circ} \mathrm{C}$, there was no significant difference $(p>0.05)$ in protein concentration at the different $\mathrm{pH}$ values, while a lower protein extraction yield was obtained from soaking at $\mathrm{pH}$ 3.0. This resulted in a lower weight of soybean milk than those obtained at $\mathrm{pH} 9$ and neutral $\mathrm{pH}$, as shown in Fig. 6. In contrast, a higher weight of soymilk was obtained at pH 9 due to the high solubility of extracted protein.

Fig. 6 shows the changes in the solid extraction yields as a function of $\mathrm{pH}$ and soaking time. For soaking at $\mathrm{pH}$ 9, the maximum solid extraction yields were $66.35 \% .67 .30 \%$ and $58.24 \%$ after $15 \mathrm{~h}, 10 \mathrm{~h}$ and $2 \mathrm{~h}$ of incubation at $4{ }^{\circ} \mathrm{C}, 25^{\circ} \mathrm{C}$, and $50{ }^{\circ} \mathrm{C}$, respectively. When soaked at $\mathrm{pH} 3$, the maximum solid extraction yields were $66.33 \%, 61.05 \%$ and $55.67 \%$, respectively. Therefore, the maximum solid extraction yield was the lowest at $50^{\circ} \mathrm{C}$ and $\mathrm{pH} 3$; meanwhile, at $25^{\circ} \mathrm{C}$ and $\mathrm{pH} 9$, the maximum solid extraction yield was the highest. When the soaking temperature was $4{ }^{\circ} \mathrm{C}$, the maximum solid extraction yields at pH 3 and pH 9 were higher than those from neutral soaking, and the time to reach the maximum decreased. When the soaking temperature was $50{ }^{\circ} \mathrm{C}$ or $25{ }^{\circ} \mathrm{C}$, the solid extraction yield decreased in the following order: $\mathrm{pH} 9>$ deionized water $>$
$\mathrm{pH} 3$, showing that alkaline soaking $\mathrm{pH}$ enhanced the extraction of solids. This result was very similar to the observed protein extraction yield results because the solids mainly consist of proteins. However, other components, such as saccharides, polyphenols, and isoflavones, also contributed to the solid components ${ }^{38}$ and showed different effects on the extraction yield.

3.3.2 Color and particle size of soymilk. Color is also an important property in evaluating the quality of soymilk. Under the conditions in which the highest extraction yield of protein was obtained, the influence of soaking conditions on the color of soymilk was studied using a colorimeter. The $L^{*}$ value represents the whiteness of the soymilk. Fig. 7 shows that the whiteness of the soymilk decreased as the $\mathrm{pH}$ value of the soaking solution increased. The highest whiteness of the soymilk was observed at $25{ }^{\circ} \mathrm{C}$ soaking temperature, whereas $50^{\circ} \mathrm{C}$ soaking treatment significantly decreased the whiteness value $(p<0.05)$. As stated above (Fig. 4$)$, the obtained soymilk had a low fat content at a soaking temperature of $50{ }^{\circ} \mathrm{C}$; thus, the oil body (white color) content decreased, and the whiteness decreased. The $b^{*}$ value of cooked soymilk was higher than that of raw soymilk, indicating that the color of cooked soymilk 


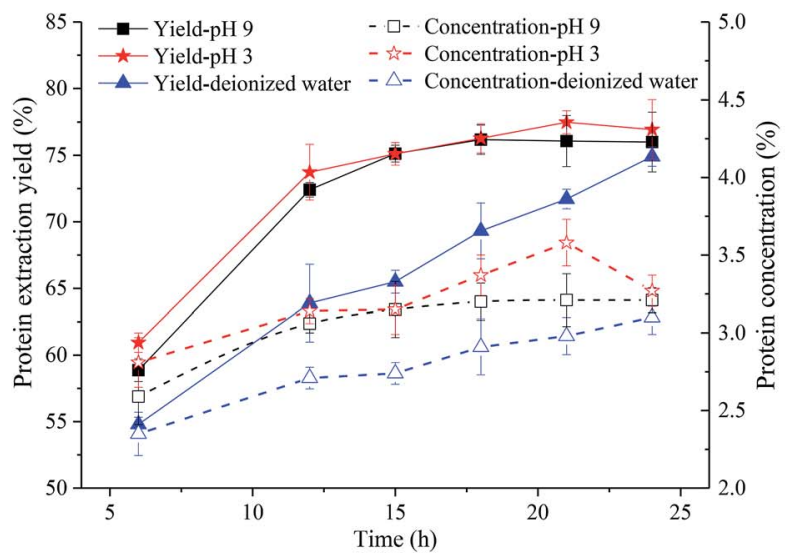

(a)

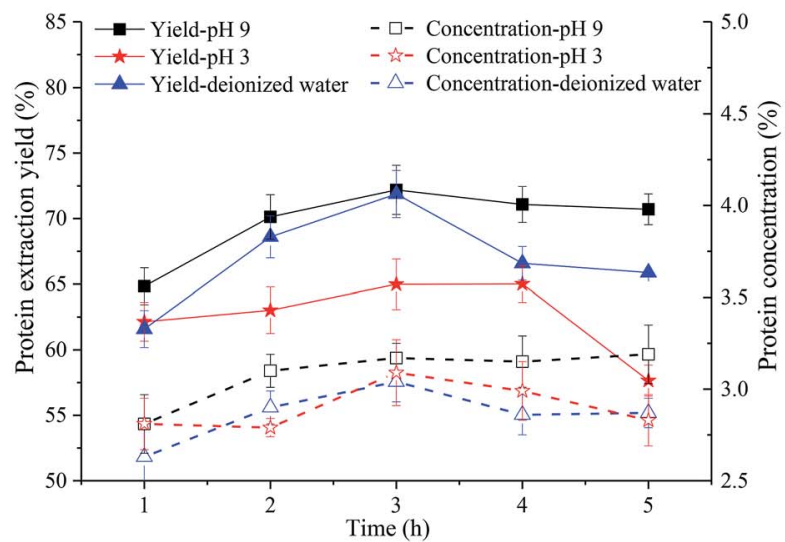

(c)

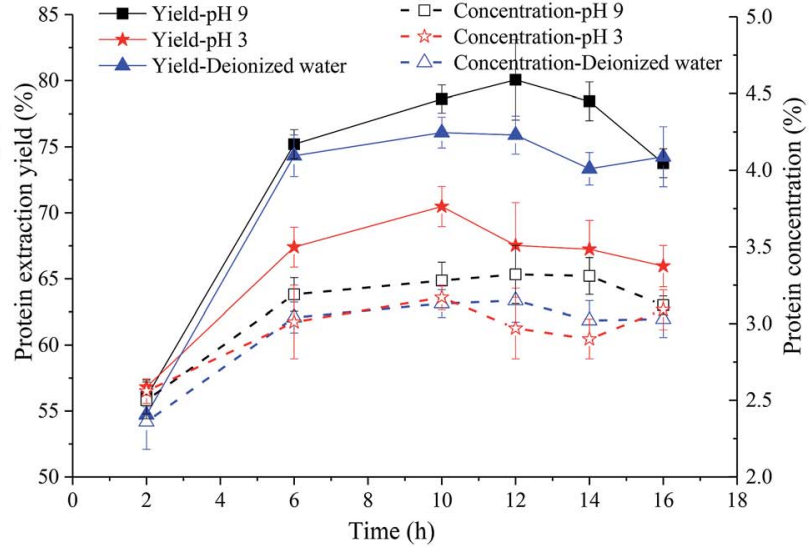

(b)

Fig. 5 Effects of the $\mathrm{pH}$ value of the soaking water on the concentration and protein extraction yield of soymilk at (a) $4{ }^{\circ} \mathrm{C}$; (b) $25^{\circ} \mathrm{C}$; (c) $50{ }^{\circ} \mathrm{C}$.

tended toward yellow. The $b^{*}$ value of the raw soymilk obtained from soaking at $\mathrm{pH} 9$ was significantly higher $(p<0.05)$ than that obtained under other soaking conditions; meanwhile, it did not change greatly after heating of the soymilk. The $a^{*}$ value represents redness or greenness; the cooked soymilk showed a lower $a^{*}$ value than the raw soymilk and thus looks greener than the latter.

Fig. 8 shows a comparison of the particle sizes of the raw and cooked soymilk as affected by different soaking temperatures and $\mathrm{pH}$ values. In soymilk, particles dispersed in the aqueous phase have different characteristics, such as oil droplets, native protein aggregates (protein bodies), and other aggregates formed from oil droplets and proteins and/or polysaccharides. ${ }^{39,40}$ For cooked soymilk, the particle size was larger than that of raw soymilk, as shown in Fig. 8. This may be due to aggregation of particles caused by denaturation of proteins, where intermolecular disulfide bonds and hydrophobic bonds between protein molecules may be formed, and the colloidal particles are coalesced to some extent. As stated above (Fig. 4-6), when the soybeans were soaked at $50^{\circ} \mathrm{C}$ and $\mathrm{pH} 3$, the obtained raw soymilk showed the lowest fat, protein and solid yields, which may be unfavorable to form a stable emulsion; at the same time, the polysaccharides may be involved in the loss of solids which also play important roles in the stability of the emulsion. Therefore, raw soymilk obtained at $50{ }^{\circ} \mathrm{C}$ and $\mathrm{pH} 3$ had higher colloidal particle sizes, and larger aggregates were more likely to form after cooking at $95{ }^{\circ} \mathrm{C}$ for $10 \mathrm{~min}$ (Fig. 8). With increasing soaking $\mathrm{pH}$, the particle size of the cooked soymilk decreased gradually. This may be due to the fact that the acid soaking $\mathrm{pH}$ causes the $\mathrm{pH}$ of the obtained soymilk to be closer to the isoelectric point ( $\mathrm{pH} 4.5$ ) of the soy proteins (which can more readily form large aggregates), while the alkaline soaking $\mathrm{pH}$ produced the opposite effect.

\subsection{Effects of soaking conditions on the release of volatile flavor compounds in soymilk}

It has been reported that the volatile compounds in soymilk mainly consist of aldehydes, alcohols, ketones, esters, phenols, and acids; these contribute to mushroom flavor, grass flavor, fat smells, fresh vegetable flavors, rose flavor, and fruit flavors. ${ }^{21}$ Kühn $e t$ al. and Lei $e t$ al. pointed out that any factors affecting the hydrophobic interactions of a protein surface will affect the binding of volatile flavor compounds. ${ }^{41,42}$ Around fifty-seven compounds were identified in the headspace of the soymilks studied in the present work; these were identified as aldehydes, 


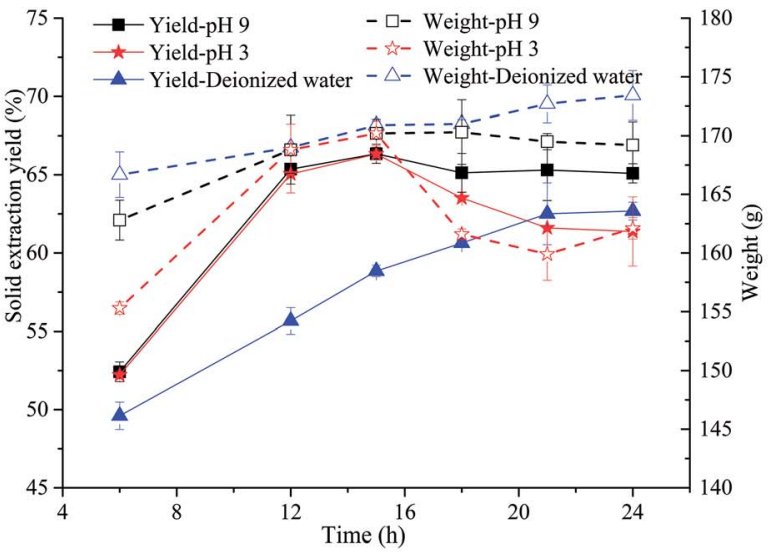

(a)

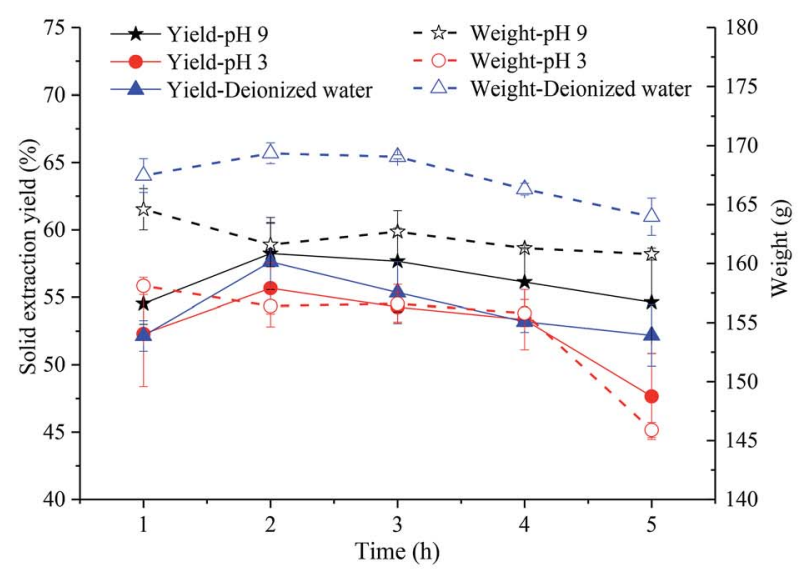

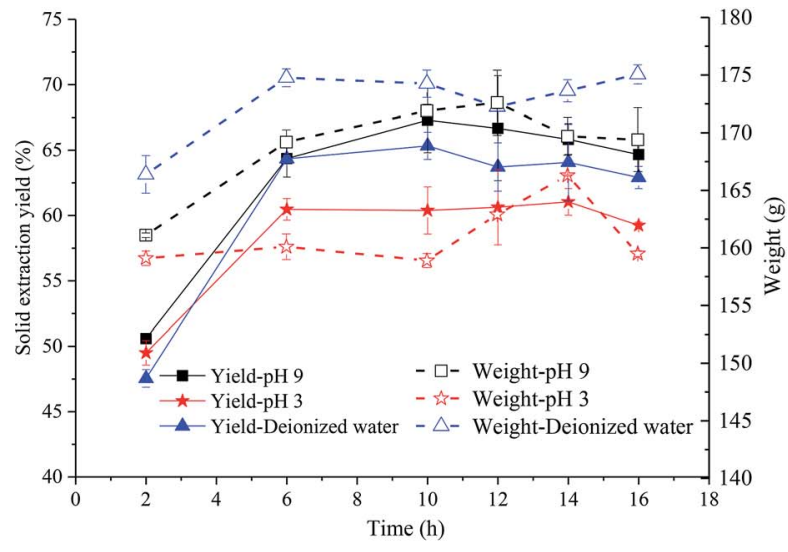

(b)

(c)

Fig. 6 Effects of the $\mathrm{pH}$ value of the soaking water on the extraction rate of solids and the weight of soymilk at (a) $4{ }^{\circ} \mathrm{C}$; (b) $25^{\circ} \mathrm{C}$; (c) $50{ }^{\circ} \mathrm{C}$.

ketones, alcohols, furans, hydrocarbons, esters and acids (Fig. 9). Table 3 shows the quantitative analysis of the typical odor components in soymilk. ${ }^{43}$

3.4.1 Aldehydes. As shown in Table 3, hexanal was the most abundant odor component identified, followed by trans-2hexenal. Other compounds were also detected at low levels, such as heptanal, octanal, benzaldehyde and pentanal (data not shown). Fig. 9 illustrates that the total concentration of aldehydes varies greatly with soaking temperature and $\mathrm{pH}$. It was found that the raw soymilk treated at $50{ }^{\circ} \mathrm{C}$ with deionized water achieved the highest level of aldehydes, while the lowest concentration of aldehydes was observed at soaking conditions of $25{ }^{\circ} \mathrm{C}$ and $\mathrm{pH}$ 9. Among the aldehydes identified in soymilk, hexanal has a low detection threshold and is considered to be the main contributor to sensory off-flavors, such as beany and grassy flavors. ${ }^{44}$ In addition, high temperature can promote the activity of lipoxygenase, which can generate the oxidation products of unsaturated lipids by catalysis. At a high soaking temperature of $50^{\circ} \mathrm{C}$ with deionized water, the hexanal level was significantly higher $(p<0.05)$ than under other soaking conditions, indicating that these conditions are very suitable for the lipoxygenase-induced oxidation reaction. trans-2-Hexenal is a leaf aldehyde which has a very strong green leaf odor, pentanal has a fatty taste, and benzaldehyde has a bitter almond flavor. After soaking at $50{ }^{\circ} \mathrm{C}$ in deionized water, the level of trans-2hexenal reached $82.22 \mu \mathrm{g} \mathrm{L}{ }^{-1}$, which is significantly higher $(p<$ $0.05)$ than the other soaking conditions.

3.4.2 Alcohols. Most volatile alcohols have grassy and cardamom flavors; they are the second most abundant volatile compounds in soymilk. As shown in Fig. 9, the total concentration of aldehydes was greatly influenced by the soaking temperature and $\mathrm{pH}$. The concentration of alcohols achieved the maximum after soaking at $50^{\circ} \mathrm{C}$ in deionized water, while it reached a minimum at $4{ }^{\circ} \mathrm{C}$ and $\mathrm{pH}$ 3. When the soaking temperature increased, the concentration of alcohol substances first increased and then decreased. Among the volatile alcohols, 1-octene-3-ol is oxidized from linoleic acid and confers a mushroomy off-flavor. ${ }^{45}$ After immersion at $4{ }^{\circ} \mathrm{C}$ and $\mathrm{pH} 3$, the content of 1-octene-3-ol was only $79.75 \mu \mathrm{g} \mathrm{L}^{-1}$; meanwhile, it reached $910.48 \mu \mathrm{g} \mathrm{L}^{-1}$ after soaking at $50^{\circ} \mathrm{C}$ in deionized water, which is nearly 12 -fold the content of the former. Additionally, the hexitol content of the soymilk obtained at $25^{\circ} \mathrm{C}$ and $\mathrm{pH} 9$ is obviously higher than those obtained under the other conditions.

3.4.3 Other volatile compounds. Among the other volatile compounds, furan exhibits an unpleasant odor in soymilk, 


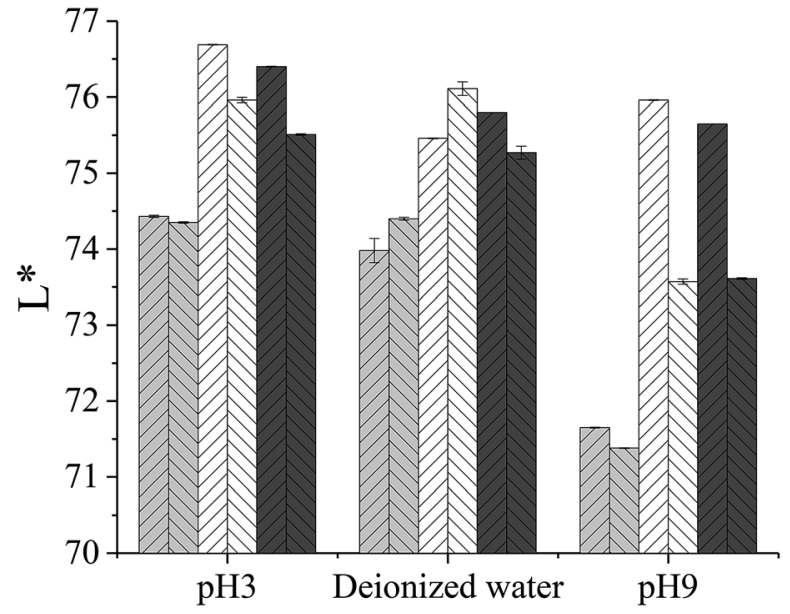

(a)

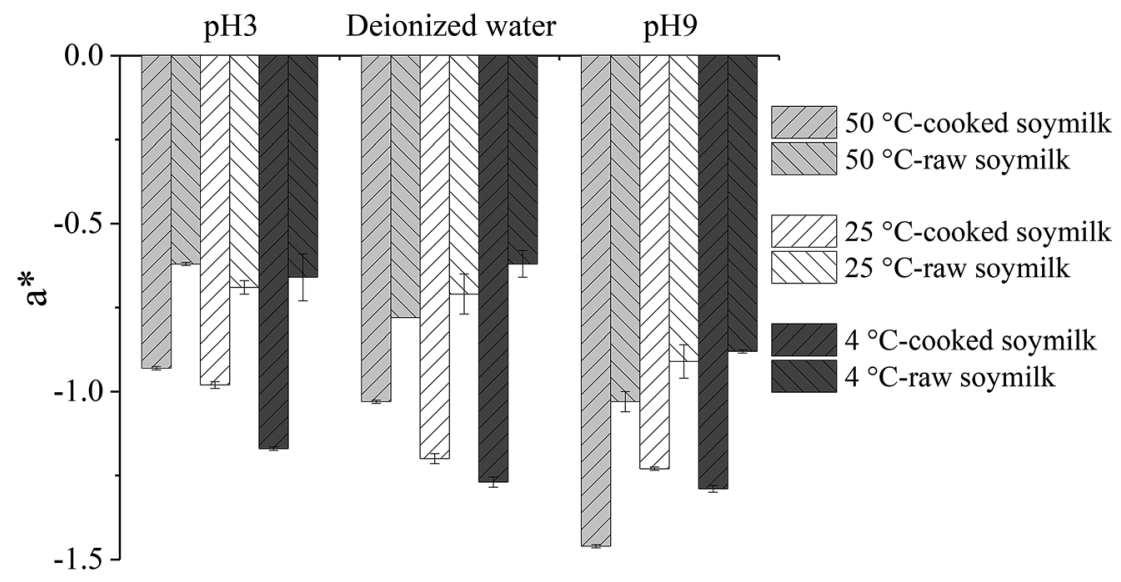

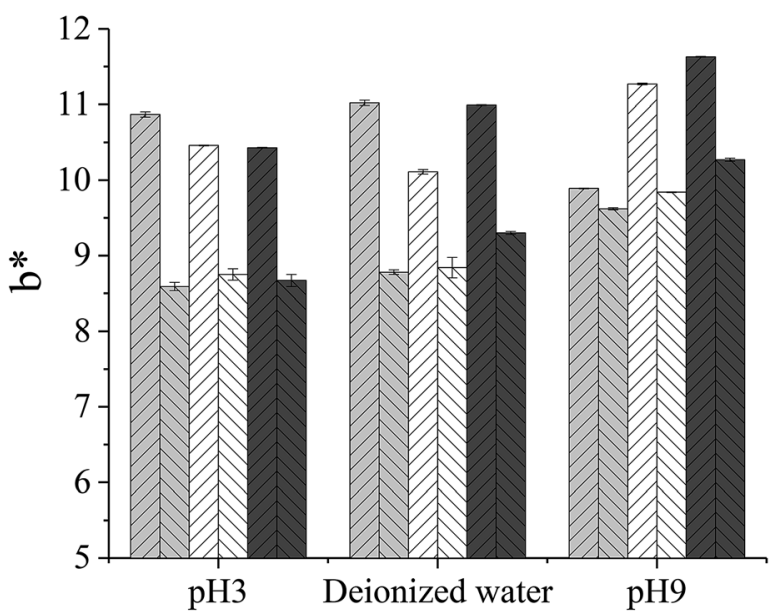

(b)

(c)

Fig. 7 Effects of soaking conditions on the color of soymilk: (a) $L^{*}$ value; (b) $b^{*}$ value; (c) $a^{*}$ value.

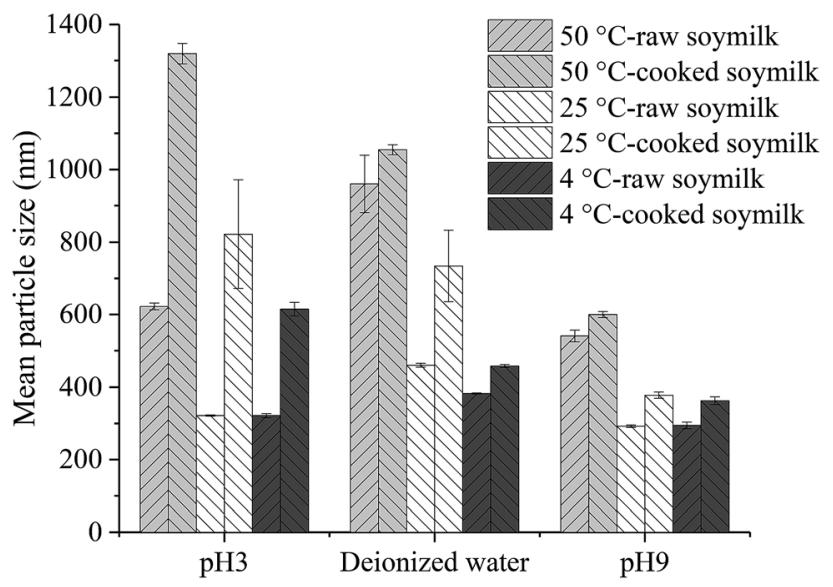

Fig. 8 Effects of soaking conditions on the particle size of soymilk.

which is mainly generated from oxidation of unsaturated fatty acids or the Maillard reaction; it is also related to the color of soymilk. Especially, 2-pentylfuran is considered to be the main contributor of grassy or beany flavors that cause soymilk to taste

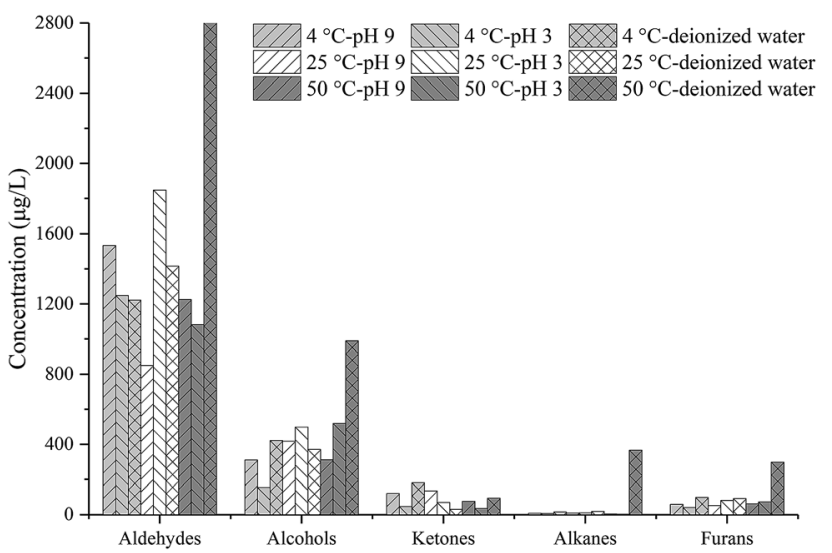

Fig. 9 Effects of soaking conditions on the volatile compounds of soymilk.

unpleasant or unacceptable. ${ }^{46}$ After soaking at $50{ }^{\circ} \mathrm{C}$ in deionized water, the content of 2-pentylfuran in soymilk reached $281.45 \mu \mathrm{g} \mathrm{mL}^{-1}$ (Table 3), which is significantly higher $(p<0.05)$ than that of the other soaking conditions. Ketones and alkanes 
Table 3 Main identified volatile compounds in soymilk determined by GC-MS ${ }^{a}$

\begin{tabular}{|c|c|c|c|c|c|}
\hline \multirow[b]{2}{*}{ Soaking conditions } & \multicolumn{5}{|c|}{ Concentration $\left(\mu \mathrm{g} \mathrm{L}{ }^{-1}\right)$} \\
\hline & Hexanal & trans-2-Hexenal & 1-Octene-3-ol & Hexanol & 2-Pentylfuran \\
\hline $4{ }^{\circ} \mathrm{C}-\mathrm{pH} 3$ & $1028.58^{\mathrm{b}}$ & $28.45^{\mathrm{b}}$ & $79.75^{\mathrm{d}}$ & $43.01^{\mathrm{c}}$ & $92.73^{\mathrm{b}}$ \\
\hline $4^{\circ} \mathrm{C}$-deionized water & $886.05^{\mathrm{bc}}$ & $21.76^{\mathrm{b}}$ & $294.41^{\mathrm{b}}$ & $83.55^{\mathrm{b}}$ & $33.73^{\mathrm{c}}$ \\
\hline $25{ }^{\circ} \mathrm{C}-\mathrm{pH} 9$ & $510.14^{\mathrm{c}}$ & $26.05^{\mathrm{b}}$ & $255.45^{\mathrm{bc}}$ & $141.23^{\mathrm{a}}$ & $50.03^{c}$ \\
\hline $50{ }^{\circ} \mathrm{C}-\mathrm{pH} 9$ & $920.96^{\mathrm{b}}$ & $18.65^{\mathrm{bc}}$ & $270.94^{\mathrm{bc}}$ & $26.47^{\mathrm{cd}}$ & $61.70^{\mathrm{bc}}$ \\
\hline $50{ }^{\circ} \mathrm{C}-\mathrm{pH} 3$ & $719.81^{\mathrm{bc}}$ & $13.29^{\mathrm{c}}$ & $478.36^{\mathrm{b}}$ & $17.71^{\mathrm{d}}$ & $67.92^{\mathrm{bc}}$ \\
\hline $50{ }^{\circ} \mathrm{C}$-deionized water & $1834.31^{\mathrm{a}}$ & $82.22^{\mathrm{a}}$ & $910.48^{\mathrm{a}}$ & $28.11^{\mathrm{cd}}$ & $281.45^{\mathrm{a}}$ \\
\hline
\end{tabular}

are the other two volatile compounds detected at low levels. Ketones are mainly derived from linoleic acid and have creamy or fruity aromas; they make little contribution to the off-flavor of soymilk compared to aldehydes and alcohols. Alkanes are mainly composed of olefins and alkanes; because of their low concentration and high detection thresholds, they also contribute little to the off-flavor of soymilk.

\section{Conclusion}

The effects of water absorption of soybeans during the soaking and heating processes in soymilk production on the protein, fat and solid extraction of soymilk and their relationships to the release of volatile flavor compounds were investigated in this study. The water absorption rate increased with increasing soaking temperature and $\mathrm{pH}$, and similar maximum moisture contents were obtained after reaching the saturation soaking time. Peleg's equation with good fitting of the absorption kinetics can be used to predict the hydration characteristics of soybean soaking under other conditions (different $\mathrm{pH}$ values and temperatures). Basic 7S globulin was identified as the most released protein during soaking; it showed the highest content after $50{ }^{\circ} \mathrm{C}$ soaking treatment. For raw soymilk, the relatively highest extraction yield of proteins, fat and solids was obtained after soaking at $25^{\circ} \mathrm{C}$ and $\mathrm{pH} 9$; they had no positive correlation with water adsorption. Hexanal, trans-2-hexenal, 1-octene-3-ol, hexanol, and 2-pentylfuran were the main identified volatile offflavor compounds of soymilk; their contents significantly increased after soaking at high temperature. Soaking at low temperature $\left(4{ }^{\circ} \mathrm{C}\right.$ and $\left.25{ }^{\circ} \mathrm{C}\right)$ with deionized water or $\mathrm{pH} 3$ solution enables the soymilk to retain relatively low odor profiles compared to the other soaking conditions.

\section{Conflicts of interest}

There are no conflicts to declare.

\section{Acknowledgements}

This study was supported by the National Natural Science Foundation of China (No. 31801590), the Nature Science
Foundation of Jiangsu Province (Grants No. BK20180609 and BK20160168).

\section{References}

1 T. Larkin, W. E. Price and L. Astheimer, The key importance of soy isoflavone bioavailability to understanding health benefits, Crit. Rev. Food Sci. Nutr., 2008, 48(6), 538-552.

2 D. O. Otieno, J. F. Ashton and N. P. Shah, Evaluation of enzymic potential for biotransformation of isoflavone phytoestrogen in soymilk by Bifidobacterium animalis, Lactobacillus acidophilus and Lactobacillus casei, Food Res. Int., 2006, 39(4), 394-407.

3 L. P. Bricarello, N. Kasinski, M. C. Bertolami, A. Faludi, L. A. Pinto, W. G. Relvas, M. C. Izar, S. S. Ihara, S. Tufik and F. A. Fonseca, Comparison between the effects of soy milk and non-fat cow milk on lipid profile and lipid peroxidation in patients with primary hypercholesterolemia, Nutrition, 2004, 20(2), 200-204.

4 Z. Pan and W. Tangratanavalee, Characteristics of soybeans as affected by soaking conditions, LWT-Food Sci. Technol., 2003, 36(1), 143-151.

5 D.-J. Shin, W. Kim and Y. Kim, Physicochemical and sensory properties of soy bread made with germinated, steamed, and roasted soy flour, Food Chem., 2013, 141(1), 517-523.

6 N. Abu-Ghannam and B. McKenna, The application of Peleg's equation to model water absorption during the soaking of red kidney beans (Phaseolus vulgaris L.), J. Food Eng., 1997, 32(4), 391-401.

7 M. Joshi, B. Adhikari, J. Panozzo and P. Aldred, Water uptake and its impact on the texture of lentils (Lens culinaris), $J$. Food Eng., 2010, 100(1), 61-69.

8 S. Shafaei, A. Masoumi and H. Roshan, Analysis of water absorption of bean and chickpea during soaking using Peleg model, J. Saudi Soc. Agric. Sci., 2016, 15(2), 135-144.

9 B. S. Adesina, T. Olayanju, O. Dairo, B. Bolaji and O. Sobukola, Applicability of peleg's equation in predicting water absorption during the soaking of Ofada and Nerica (L1) rice, J. Postharvest Technol., 2017, 5(4), 51-61.

10 O. Paquet-Durand, V. Zettel, R. Kohlus and B. Hitzmann, Optimal design of experiments and measurements of the 
water sorption process of wheat grains using a modified Peleg model, J. Food Eng., 2015, 165, 166-171.

11 D. H. Wardhani, J. A. Vázquez and S. S. Pandiella, Kinetics of daidzin and genistin transformations and water absorption during soybean soaking at different temperatures, Food Chem., 2008, 111(1), 13-19.

12 S. Giri and S. Mangaraj, Processing influences on composition and quality attributes of soymilk and its powder, Food Eng. Rev., 2012, 4(3), 149-164.

13 W. F. Wilkens and L. Hackler, Effect of processing conditions on the composition of soy milk, Cereal Chem., 1969, 46, 391-397.

14 A. M. Nik, S. M. Tosh, L. Woodrow, V. Poysa and M. Corredig, Effect of soy protein subunit composition and processing conditions on stability and particle size distribution of soymilk, LWT-Food Sci. Technol., 2009, 42(7), 1245-1252.

15 A. Torres-Penaranda and C. Reitmeier, Sensory descriptive analysis of soymilk, J. Food Sci., 2001, 66(2), 352-356.

16 A. Badenhop and W. Wilkens, The formation of 1-octen-3-ol in soybeans during soaking, J. Am. Oil Chem. Soc., 1969, 46(3), 179-182.

17 E. Y. Ha, C. V. Morr and A. Seo, Isoflavone aglucones and volatile organic compounds in soybeans; effects of soaking treatments, J. Food Sci., 1992, 57(2), 414-417.

18 M. Peleg, An Empirical Model for the Description of Moisture Sorption Curves, J. Food Sci., 1988, 53(4), 12161217.

19 X. Li, J. Long, Y. Hua, Y. Chen, X. Kong and C. Zhang, Protein Separation Coacervation with Carboxymethyl Cellulose of Different Substitution Degree: Noninteracting Behavior of Bowman-Birk Chymotrypsin Inhibitor, J. Agric. Food Chem., 2018, 66(17), 4439-4448.

20 X. Li, Y. Hua, Y. Chen, X. Kong and C. Zhang, Protein Selectivity Controlled by Polymer Charge Density and Protein Yield: Carboxylated Polysaccharides versus Sulfated Polysaccharides, J. Agric. Food Chem., 2016, 64(47), 90549062.

21 A. Achouri, J. I. Boye and Y. Zamani, Identification of volatile compounds in soymilk using solid-phase microextractiongas chromatography, Food Chem., 2006, 99(4), 759-766.

22 R. Chopra and D. Prasad, Standardization of soaking conditions for soybean seeds/cotyledons for improved quality of soymilk, Indian J. Anim. Sci., 1994, 64(4), 405-410.

23 A. N. C. Resio, R. J. Aguerre and C. Suarez, Analysis of simultaneous water absorption and water-starch reaction during soaking of amaranth grain, J. Food Eng., 2005, 68(2), 265-270.

24 A. Gowen, N. Abu-Ghannam, J. Frias and J. Oliveira, Influence of pre-blanching on the water absorption kinetics of soybeans, J. Food Eng., 2007, 78(3), 965-971.

25 S. Cunningham, W. McMinn, T. Magee and P. Richardson, Modelling water absorption of pasta during soaking, $J$. Food Eng., 2007, 82(4), 600-607.

26 B. K. Yadav and V. K. Jindal, Modeling Varietal Effect on the Water Uptake Behavior of Milled Rice (Oryza sativa L.) during soaking, J. Food Process Eng., 2007, 30(6), 670-684.
27 S. M. Shafaei and A. A. Masoumi, Studying and Modeling of Hydration Kinetics in Chickpea Seeds (Cicer arietinum L.), Agricultural Communications, 2014, 2(2), 15-21.

28 K. J. Laidler, The development of the Arrhenius equation, $J$. Chem. Educ., 1984, 61(6), 494.

$29 \mathrm{~V}$. Jideani and S. Mpotokwane, Modeling of water absorption of Botswana bambara varieties using Peleg's equation, $J$. Food Eng., 2009, 92, 182-188.

30 G. Shun-Tang, T. Ono and M. Mikami, Interaction between Protein and Lipid in Soybean Milk at Elevated Temperature, J. Agric. Food Chem., 1997, 45(12), 4601-4605.

31 C. Y. Ma, W. S. Liu, K. C. Kwok and F. Kwok, Isolation and characterization of proteins from soymilk residue (okara), Food Res. Int., 1996, 29(8), 799-805.

32 S. Dhaubhadel, K. Kuflu, M. C. Romero and M. Gijzen, A soybean seed protein with carboxylate-binding activity, $J$. Exp. Bot., 2005, 56(419), 2335-2344.

33 K. Fujiwara, C. Cabanos, K. Toyota, Y. Kobayashi and N. Maruyama, Differential expression and elution behavior of basic 7S globulin among cultivars under hot water treatment of soybean seeds, J. Biosci. Bioeng., 2014, 117(6), 742-748.

$34 \mathrm{H}$. Hirano, H. Kagawa and K. Okubo, Characterization of proteins released from legume seeds in hot water, Phytochemistry, 1992, 31(3), 731-735.

35 H. Kagawa, H. Hirano, M. Tomotake and F. Kikuchi, A seed protein induced by heat treatment in soybean (Glycine max (L.)), Food Chem., 1993, 48(2), 159-163.

36 M. H. Palavalli, S. S. Natarajan, T. T. Wang and H. B. Krishnan, Imbibition of soybean seeds in warm water results in the release of copious amounts of Bowman-Birk protease inhibitor, a putative anticarcinogenic agent, J. Agric. Food Chem., 2012, 60(12), 3135-3143.

37 J. M. Renkema, H. Gruppen and T. Van Vliet, Influence of $\mathrm{pH}$ and ionic strength on heat-induced formation and rheological properties of soy protein gels in relation to denaturation and their protein compositions, J. Agric. Food Chem., 2002, 50(21), 6064-6071.

38 B. Xu and S. K. C. Chang, Total Phenolics, Phenolic Acids, Isoflavones, and Anthocyanins and Antioxidant Properties of Yellow and Black Soybeans As Affected by Thermal Processing, J. Agric. Food Chem., 2008, 56(16), 7165-7175.

39 N. Cruz, M. Capellas, M. Hernández, A. J. Trujillo, B. Guamis and V. Ferragut, Ultra high pressure homogenization of soymilk: Microbiological, physicochemical and microstructural characteristics, Food Res. Int., 2007, 40(6), 725-732.

40 A. Malaki Nik, S. Tosh, V. Poysa, L. Woodrow and M. Corredig, Physicochemical characterization of soymilk after step-wise centrifugation, Food Res. Int., 2008, 41(3), 286-294.

41 J. Kühn, T. Considine and H. Singh, Interactions of milk proteins and volatile flavor compounds: implications in the development of protein foods, J. Food Sci., 2006, 71(5), R72-R82. 
42 Q. Lei and W. Boatright, Compounds contributing to the odor of aqueous slurries of soy protein concentrate, J. Food Sci., 2001, 66(9), 1306-1310.

43 S. Yuan and S. K.-C. Chang, Selected odor compounds in soymilk as affected by chemical composition and lipoxygenases in five soybean materials, J. Agric. Food Chem., 2007, 55(2), 426-431.

44 H. Ma, C.-Y. Guan, X.-L. He, G.-Z. Zhang and A.-L. Din, Effects of lipoxygenase null genes of soybean in controlling beany-flavor of soymilk and soyflour, Agric. Sci. China, 2002, 1(9), 965-971.

45 R. Yang and H. Jiang, Analysis of Aroma Components in Soybean Milk with Different Pretreatments by SDE-GC-MS Based on Retention Index, Shipin Kexue, 2015, 20, 035.

46 S. Min, Y. Yu, S. Yoo and S. S. Martin, Effect of Soybean Varieties and Growing Locations on the Flavor of Soymilk, J. Food Sci., 2005, 70(1), C1-C11. 